\title{
THE CITY IDENTITY: A HERO PERSONAGE AS CITY BRANDING
}

\author{
Eli Jamilah Mihardja, Universitas Bakrie, Jakarta \\ Prima Mulyasari Agustini, Universitas Bakrie, Jakarta \\ M. Bisyri, Universitas Fajar, Makassar
}

\begin{abstract}
Kabupaten Pinrang identifies itself as the Land of La Sinrang (Bumi La Sinrang) and marks its city with many land marks regarding figure La Sinrang as their hero. However, it is not yet known the acceptance of the city residents regarding the determination of that identity. This research is part of the research on the formulation of city branding in Kabupaten Pinrang in the PDUPT scheme of the Ministry of Higher Education Ministry of Higher Education 2018. Data was collected through survey, interviews, observation and literature study. The results showed that La Sinrang as Pinrang Regency's city identity was accepted as a result of policy but not included as a city branding option by young people based on social media.
\end{abstract}

Keywords: city branding, city identity, Pinrang 


\section{Introduction}

Pinrang is one of the districts in South Sulawesi. Pinrang Regency has an area of 1,967 sq km, has an administrative area of 12 sub-districts, and consists of 39 sub-districts and 69 villages covering 81 neighborhoods and 168 hamlets. Pinrang Regency is mainly in the north bordering the Tana Toraja Regency, an internationally known tourism destination.

Pinrang Regency is one of the rice production centers in South Sulawesi Province which includes the Bosowasipilu Area (rice production center) with a potential rice field area of \pm $44,851 \mathrm{Ha}$ (22.87\% of the area of Pinrang Regency).

In Pinrang Regency, tourism activities are one of the sectors that need to be boosted by developing tourism destinations, considering that the tourism sector will be able to develop a multiplier effect related sectors. The development plan for the tourism sector in Pinrang Regency consists of cultural tourism, natural tourism, and artificial tourism

La Sinrang Monument is one of tourism objects. Likewise with La Sinrang Park and various places that bear the name of La Sinrang others. La Sinrang, according to the literature, is the son of the Pinrang area who fought against Dutch colonialism until the end of his life (Nasruddin, 2016). The name La Sinrang is widely used as a place name in Pinrang, there is even a La Sinrang Park in the city center. The La Sinrang statue also stands as an icon of the city. The mention of Bumi La Sinrang is pinned to Pinrang district.

According to several sources and observations, the determination of heroes as a city icon was used by several districts in South Sulawesi. For example, Bumi Nene Mallomo is the term for Sidrap Regency and Bumi Pong Tiku Toraja. Determination of the city's icon is the highest award for heroes who won independence. However, there is no known audience acceptance of the city's icon, especially among young people.

However, the ideological identity related to the figure of La Sinrang is said to be a city identity, but to become a brand, special strategies are needed; especially related to the internalization of the values of this figure among young people. This study intends to explore how the acceptance of young people in Pinrang, especially the millennials, who are close to the use of social media about La Sinrang's hero personage as their icon and identity of the city.

\section{City Identity and City Branding}

The terms "identity" means something that refers to a persistent sameness and unity so that differentiation from others is entailed. City identity can be technically defined as an effort to seek persistent things in urban mutation and bring them up as a permanent asset. (Inn, 2004). So, city identity in this study is interpreted as an effort to find permanent assets to be recognized as the property and characteristics of the city, in this case Pinrang. 
Quoted Riza,, Doratli, and Fasli., 2012, Lynch (1960) defines identity as "the extent to which a person can recognize or recall a place as being distinct from other places". Accordingly, identity is distinction which is obvious and visible at first sight, as well as the image of people who even seen it before. Therefore, identity is always exclusive and not reproducible. Each city has a unique identity, which is an image that is either negative or positive. The image of the city is composed of monumental buildings, public spaces and other special features. From a city to a city branding perspective, many cities now promote themselves through the aid of iconic artifacts (Riza, Doratli, and Fasli., 2012).

In relation to city branding, cities are in search for new ways to promote themselves. Due to fast changes in technology and the shift from local to a globalized environment, cities are forced to compete with each other in order to be an attractive tourist destination, workplace, cultural place and much more (Kotler, 2002). City branding has to be concerned with how culture and history, economic growth and social development, infrastructure and architecture, landscape and environment, among other things, can be combined into a saleable identity that is acceptable to all people. '(Zhang, 2009 ,)

However, in this case, the study of Riza, Doratli, and Fasli., 2012 is about the iconic architecture of the contemporary city and its image and identity. Iconic architecture can be just an appropriate tool for city branding if the building is not reproducible, but context sensitive. It should not be forgotten, that cities are unique and have their own identity formed and affected by people, social, natural and manmade factors as well as many other effects (Fasl1, 2010).

According to Abalmasova and Pain (2011), the determination of heroes as icons and city identity is Symbolic management in creating regional identity. La Sinrang is a symbol of Pinrang district. La Sinrang's figure also represents the personality of every Pinrang resident. In addition, Pinrang residents are required to emulate the heroism of La Sinrang and at the same time embed the figure of La Sinrang as his personality in terms of being a citizen of Pinrang. Hero figures are also treated as representations of their culture as in the study of Childers (1968) regarding the hero of Spain.

The figure of La Sinrang as an icon of Pinrang was one of the Bugis fighters from Pinrang who led the young people in the land of Addatuang (kingdom) Sawitto against the Dutch invaders. 
Lasinrang was born in the village of Dolangan, Pinrang in 1856 and died in 1936. In the history, Lasinrang was one of the fighters who could not be defeated by the Dutch during the colonial period. It was the cruel tactics of the Dutch who arrested his father, Addatuang Sawitto, and his wife, I Makkanyuma, which made Lasinrang surrender. Pinrang residents capture the name Lasinrang in every corner of the city as the name of the street, gymnasium, hospital and others. Even the gold-haired Lasinrang statue stands tall in the center of Pinrang City, which is about 185 kilometers from Makassar City. (Nasrudin, 2016).

According to Risnoyanto (2016), locations that reflect the legacies of La Sinrang's struggle were developed and used as historical sites. These locations are tourist destinations in Pinrang Regency (RJPMD Pinrang 2016). La Sinrang's figure is also actively socialized as an icon of Pinrang Regency.

\section{Methodology}

We used mix-method; consist of quantitative survey with questionnaire and qualitative methods with focus group discussion and in-depth interviews. A simple-Quantitative survey has conducted to identify the perception of Pinrang's young people toward their hero personage. We use in-depth interview with source from Dinas Pariwisata, Pemuda dan Olahraga, Dinas Informatika dan Komunikasi, and Badan Pembangunan Daerah Kabupaten Pinrang. (Department of Tourism, Youth and Sports, Department of Informatics and Communications, and the Regional Development Agency Pinrang). We also has conducted focus group discussion with the representation of government, industry, community, and academician.

\section{Results and Discussion}

City identity is an important aspect that needs to be owned by a region. With a clear identity, superior characteristics, will make a region known, can even contribute to regional income, either directly or indirectly.

Since the onset of government policy to shift regional opinion which generally originates from natural resources, into income from the tourism sector, it has made city identity important to be highlighted by a region. If you look at the reasons behind the importance of city identity, then as an identity, of course there are values that must be recognized and internalized by city residents, and introduced to stakeholders. 
The Tourism Office and the Department of Communication and Information will still put forward the hero of La Sinrang as the city's identity and icon. In an interview with a Tourism Office official, it was stated that La Sinrang was an icon of Pinrang and became the identity of the town of Pinrang.

"This is a hero so if that icon is probably just what ... the design is probably ... but La

Sinrang will still be because La Sinrang has become a Pinrang icon. So La Sinrang Pinrang's name is not too ... because the name Pinrang came from ... La Sinrang, it can't (no) ... until the world is doomed."

Pinrang, as one of the districts that will be replaced by millennial generations, will certainly hope that the identity of the city can be interpreted equally by all citizens of the city. The intergenerational gap, often leads to different meanings in an object. Popular in the days of its predecessor, it became an irreplaceable idol, but not necessarily a role model in the new generation. The dilemma side will emerge if the city identity refers to regional figures or regional heroes who are so admired in the past, but whose heroism is less well known by the next generation. Pinrang is one of the districts that identify its city with a hero figure, known as La Sinrang.

Based on the survey conducted on 25 visitors to tourist attractions in Pinrang, where demographically aged between 18-24 years, all of them knew the heroine La Sinrang. However, the knowledge of visitors to this millennial generation, as much as $60 \%$, only knows the name, but does not know the history of the heroine La Sinrang. This data indicates that La Sinrang's name is quite large, but less well-known heroic history and values that can be role models for the millennial generation.

The La Sinrang statue as an icon of Pinrang Regency is known to be present by visitors to La Sinrang Regency. The statue of La Sinrang in the district center is indeed a major sight for Pinrang visitors. Visually, this statue is known by many, but for new visitors, it often questions: What statue is it? Who? And usually, city residents only answer: La Sinrang, our regional hero. Without being able to explain what values are from the character of La Sinrang.

The popularity of the heroine La Sinrang in the millennial generation, it seems less fully approved by this generation. Based on the results of this survey, only $20 \%$ of respondents agreed to La Sinrang as the Pinrang icon. This data indicates that La Sinrang's not-so-wellknown values make his character considered not to represent the region's vision and mission, which is a transit area for visitors to Tana Toraja. The peculiarity of the Pinrang region has not been able to stand out, along with the recognition of Tana Toraja in the eyes of tourists. 
La Sinrang character's name apparently is no longer fully being a role model or idol Pinrang millenial generation. The survey results indicate that there is a lack of concern (neutral statement) making La Sinrang a role model around $60 \%$. The era of information, seems to have led Pinrang millenial generation has a role-model or another idol that may be obtained from the communications media that can be easily accessed. New idols were disseminated, known as the idol of popular culture seems to be understood by the millenial generation compared to the hero of the region.

\section{Conclusion and Recommendation}

Judging from the results of the survey above, it needs a hard effort from the Pinrang district government to re-popularize La Sinrang. Pinrang's statement as Bumi La Sinrang needs to get his spirit of idol back.

Pinrang needs to personalize La Sinrang's heroic character as a city identity. Linking La Sinrang's heroic values to the superior programs of the regional government is an important aspect to facilitate the association of city identity values with La Sinrang figures.

Identification of the values of La Sinrang heroism needs to be done in detail, so that it becomes the umbrella of all city activities. Differentiation will emerge, which is a significant differentiator between the behavior of residents of Pinrang regency and other regions.

Communication, information, and education regarding the values of La Sinrang's leaders, which are implemented in regional superior programs, are needed for city residents, especially the millennial generation

\section{Acknowledgment}

This study was funded by the Ministry of Research and Universities through the Higher Education Primary Research Scheme in 2018. 


\section{References}

Abalmasova, N. E., \& Pain, E. A. (2011). Symbolic management in creating regional identity. Regional research of Russia, 1(3), 275.

Childers, T. W. (1968). The Spanish Folk Hero as a Reflection of His Culture. New York Folklore, 24(2), 113.

Danesi, M. (2011). What's in a brand name? A note on the onomastics of brand naming. Names, 59(3), 175-185.

Inn, K. (2004). Plan for city identity establishment and city marketing the case of Kimpo city. Dela, (21), 233-240.

Kavaratzis, M., \& Ashworth, G. J. (2005). City branding: an effective assertion of identity or a transitory marketing trick?. Tijdschrift voor economische en sociale geografie, 96(5), 506-514. Nasruddin, N. (2016). Sejarah dan Budaya Lokal: dari Sulawesi sampai Bima. Ditjarahnitra Sulawesi Selatan.

Risnoyanto, R. (2016). Analisis Pengembangan Dan Pemanfaatan Situs-Situs Bersejarah Di Kabupaten Pinrang (1937-2015) (Doctoral dissertation, Pascasarjana).

Riza, M., Doratli, N., \& Fasli, M. (2012). City branding and identity. Procedia-Social and Behavioral Sciences, 35, 293-300.

Zhou, B., Liu, L., Oliva, A., \& Torralba, A. (2014, September). Recognizing city identity via attribute analysis of geo-tagged images. In European conference on computer vision (pp. 519534). Springer, Cham. 